\title{
BIOLOGICAL ASPECTS, DENSITY, AND DISTRIBUTION OF THE ALFONSINO (Beryx splendens) IN THE INDIAN OCEAN EKSLUSIVE ECONOMIC ZONE OF INDONESIA
}

\author{
Fayakun Satria1), John Haluan"2), Eko Sri Wiyono2), and Wudianto ${ }^{1)}$ \\ 1) Research Center for Capture Fisheries, Ancol-Jakarta \\ 2) Faculty of Fisheries and Marine Science, Bogor Agricultural University, Bogor \\ Received October 6-2008; Received in revised form Nopember 10-2008; Accepted Nopember 20-2008
}

\begin{abstract}
Deep water fisheries resources in the Indian Ocean ekslusive economic zone of Indonesia, has been investigated extensively in the year of 2004 to 2005. Recently a fishing operation of deep sea bottom trawl vessel F/B. Koshin Maru 01 from January to May 2008 has been attempted at around the Simeulue Island. One of a target fish was the Alfonsino, Beryx splendens. Based on the data obtained from Indonesia-Japan deep sea fisheries joint exploration program and catch data of F/B. Koshin Maru 01 the distribution, density, and biology of the Alfonsino will be analyzed. The fish was found distribute along southern of Jawa and western of Sumatera. The stock density was $68.56 \mathrm{~kg} \mathrm{~km}^{-2}$ in southern of Jawa and $607.79 \mathrm{~kg} \mathrm{~km}^{-2}$ in western of Sumatera with particularly abundant at western of the Simeulue Island. The catch rate was bigger in the depth range of 500 to $700 \mathrm{~m}$, while the size of fish was bigger in the deeper part. The population of the species was dominated by male $(60 \%)$ with two age groups that represented by the length of approximately 26 and $32 \mathrm{~cm}$. Female Alfonsino are likely consisted of three age groups represented by the length groups of approximately 26,32 , and 36 $\mathrm{cm}$ with length of first maturity $(\mathrm{Lm})$ was $33 \mathrm{~cm}$. The main diet was mainly shrimps (Sergestes spp). F/B Koshin Maru no 01 has substantially caught smaller size than Lm of the Alfonsino. This should become a warning to the fisheries manager that the recent practice of deep sea bottom trawl will endanger the resources.
\end{abstract}

KEYWORDS: distribution, density, first maturity, alfonsino, Indian Ocean

\section{INTRODUCTION}

The Alfonsino (Beryx splendens) has been known as an economic important deep sea demersal fish. The fish was reported reach for about $\$ 4.5$ per $\mathrm{kg}$ bulk in Melbourne Australia fish whole market and become one of major fisheries in New Zealand since 1988 (Clark \& Richard, 2003). Recently, Indonesia-Japan Joint exploration of deep sea fisheries resources reported that the Alfonsino (Beryx splendens) occurred wide spread in the Indian Ocean ekslusive economic zone of Indonesia (Anonymous, 2006). There was no commercial fishing utilized the resources until the end of 2007 .

During January to May 2008, Indonesia government gave permit a deep sea bottom trawl, F/B Koshin Maru No 01 to conduct an experimental commercial fishing to exploit the resources. The total catch from January $8 \mathrm{t}^{\mathrm{t}}$ to February $29^{\text {th }}$ was about 272 tones which $49.6 \%$ of the catch was the Alfonsino (Beryx splendens). The tissue content analysis reported by Suseno et al. (2007) revealed the fish has a good content for human health such as protein $23 \%$, fat $2 \%$, and 17 important amino acids with leusin $(0.50 \%)$ and fenilalanin $(0.97 \%)$ were dominant in quantity. It is likely that the Alfonsino (Beryx splendens) will become a future main target species for the deep sea demersal fishery in the Indian Ocean ekslusive economic zone of Indonesia.

In line with the possibility to utilize the resource it was reported that the resilience of this species is low with minimum population doubling time 4.5 to 14 years $(K=0.10-0.18 ; \quad t m=5-7.5 ; \quad t \max =23$; $\mathrm{Fec}=270,000)$ thus the fish categorized has high to very high vulnerability (65.28). Maximum size was reported reach to $70.0 \mathrm{~cm}$ TL (male) weight: $4,000 \mathrm{~g}$ with maximum age: 23 years (Maul, 1990), Thus the utilization of the resources should be done with precautionary approach.

The Indonesia-Japan joint exploration project within 2004 to 2005 has informed the deep sea demersal resources in general. However there was very little information of the Alfonsino (Beryx splendens). In this paper the distribution, density, sex ratio, maturity, length of first mature, and the diet of Beryx splendens from the depth of 200 to $1,000 \mathrm{~m}$, especially in the western of Aceh, Indian Ocean ekslusive economic zone of Indonesia will be described. The distribution of length size of the Alfonsino gathered from recent practice of deep sea fisheries in the western of Aceh waters (Simeulue Island) will also be presented to know the actual practice of a commercial deep sea bottom trawl fishing boat. 


\section{MATERIALS AND METHODS}

The data of this species were originated from research vessel Baruna Jaya IV cruises conducted during $2^{\text {nd }}$ of July 2005 to $3^{\text {rd }}$ of September 2005 in the framework of the Indonesia-Japan deep sea fisheries resources joint exploration marine research. Deep sea trawl used as a sample gear in the survey was described as head rope $=36 \mathrm{~m}$, ground rope $38 \mathrm{~m}$, headline height of 3.5 to $4 \mathrm{~m}$, wings tip spread of 24 $\mathrm{m}$, and was fished with a $40 \mathrm{~mm}$ liner in the cod end, and heavy rubber bobbin ground gear exploratory fishing covered the depth range of 200 to $1,000 \mathrm{~m}$, while data analyses in this paper was limited to the biological aspects, density, and distribution of the Alfonsino (Beryx splendens). Additional catch data of the fish were obtained from the fishing operation of $F /$ B. Koshin Maru 01 in the western of Simeulue Island from January to May 2008. The data were analyzed to show the length size distribution of the Alfonsino caught by the fishing boat.

\section{Analyses of Distribution and Density}

Based on catch rate data, estimation of stock density was calculated by using swept area method. The models were based on the trawled area, speed, towing time, net opening, and the catches (Sparre \& Venema, 1992) i.e:

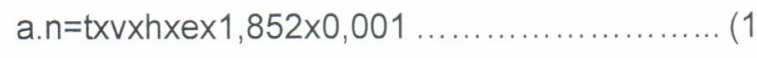

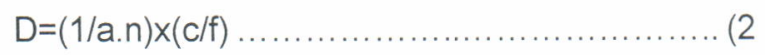

di mana:

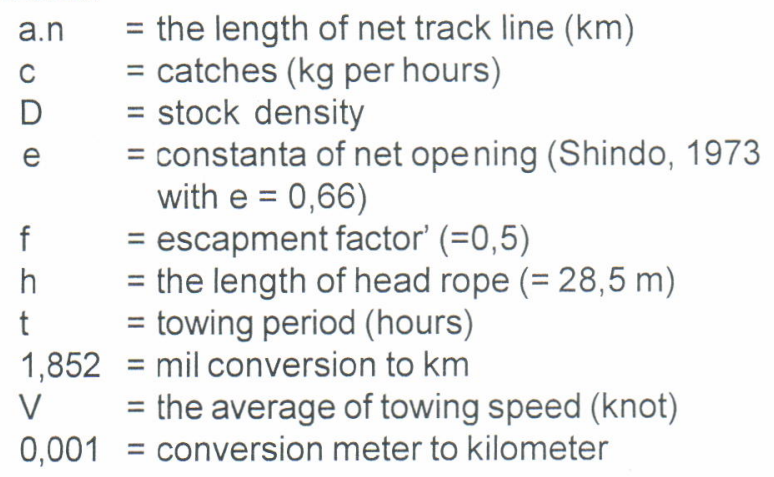

The mean catch rate will figured by depth range while the estimation of stock density will plotted to the map in order to gain insight of the spatial distribution of the fish.

\section{Biological Measurement}

Biological information i.e. length size distribution, sex ratio, gonad weight, and stomach content were based on sampled of the Alfonsino that examined on board during the cruise. Length of first maturity was calculated following Udupa (1986) in Badrudin et al. (2007) as presented in Table 2. The stages of maturity were classified into four stages with visual method i.e. mature (with globules and transparent of eggs on the gonad with bright in color), maturing (very few globules and white in color), immature (no globules, small in size and weight) and spent (the gonad of membrane appear distract) (Anonymous 2006). Breeding proportion index was the proportion of total number of gonad to the number of mature gonad. Gonad somatic index was the percentage of the proportion of gonad weight to the body weight.

\section{RESULTS AND DISCUSSION}

\section{The Species}

In the field of systematic ichthyology Beryx splendens was classified in the family of Berycidae. In the family of berycidae there are four species that is Centroberyx druzhinini, Beryx decadactylus, Beryx mollis, and Beryx splendens. The morphology of Alfonsino (Beryx splendens) (Figure 1) is dorsal spines (total): 4 to 4 ; dorsal soft rays (total): 13 to 16 ; anal spines: 4; Anal soft rays: 26 to $30 ; P_{1} 16$ to $18 ; P_{2} I$, 9 to 11 ; LL 65 to 73 . First infraorbital bone with a spine projecting laterally on anterior end. Lateral line extends to caudal fin. A fleshy disk on inner face of exposed area of scale. In young fishes, the $2^{\text {nd }}$ dorsal ray is elongate, notes pectoral fins with one spine and 17 soft rays (Nakabo, 2000).

\section{Distribution and Density}

Beryx splendens was found distribute along southern of Jawa and western of Sumatera. The fish was caught in 15 of a total of 102 trawls in the study area $(14.7 \%)$. There was a concentration of relatively big catches in the station no 067 for about $77 \mathrm{~kg}(\mathrm{n}=$ 147) located west of Simeulue Island at depth $519 \mathrm{~m}$ and station no 020 for about $3.87 \mathrm{~kg}(n=102) \mathrm{kg}$ located west of Barung Island at depth $335 \mathrm{~m}$. The catches from individual stations are plotted with symbol size proportional to the numbers in the catch in Figure 2. The populations were not found as shift to the West starting from $108^{\circ} \mathrm{E}$ until Enggano Island. Beryx splendens was also occurred around Enggano waters in relatively small quantity and small body size. 
Biological Aspects, Density, and Distribution ..... Ekslusive Economic Zone of Indonesia (Satria, F., et al.)

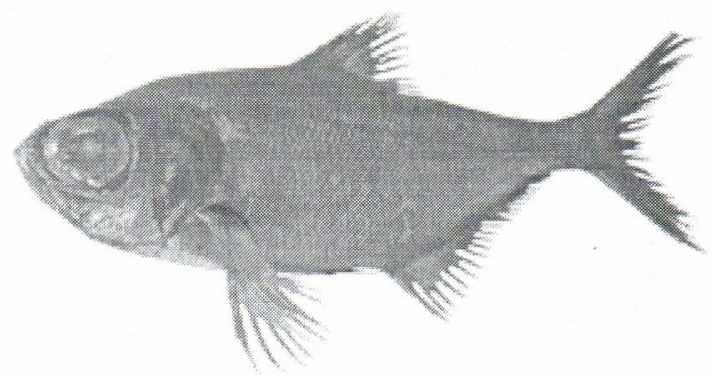

Figure 1. The Alfonsino (Beryx splendens) $(T L=36.5 \mathrm{~cm} ; \mathrm{W}=510 \mathrm{~g})$.
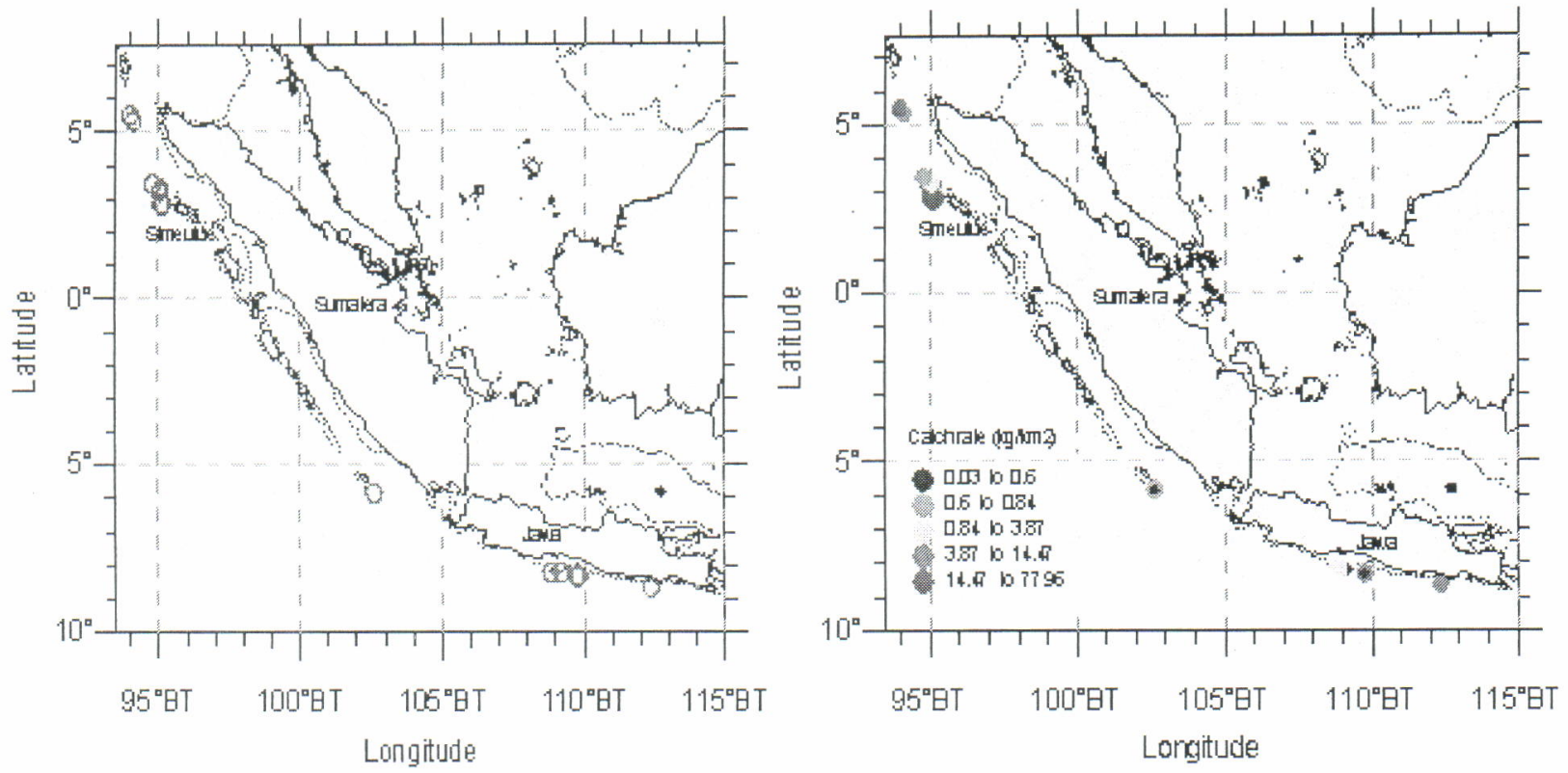

Figure 2. Horizontal distribution of Beryx splendens.

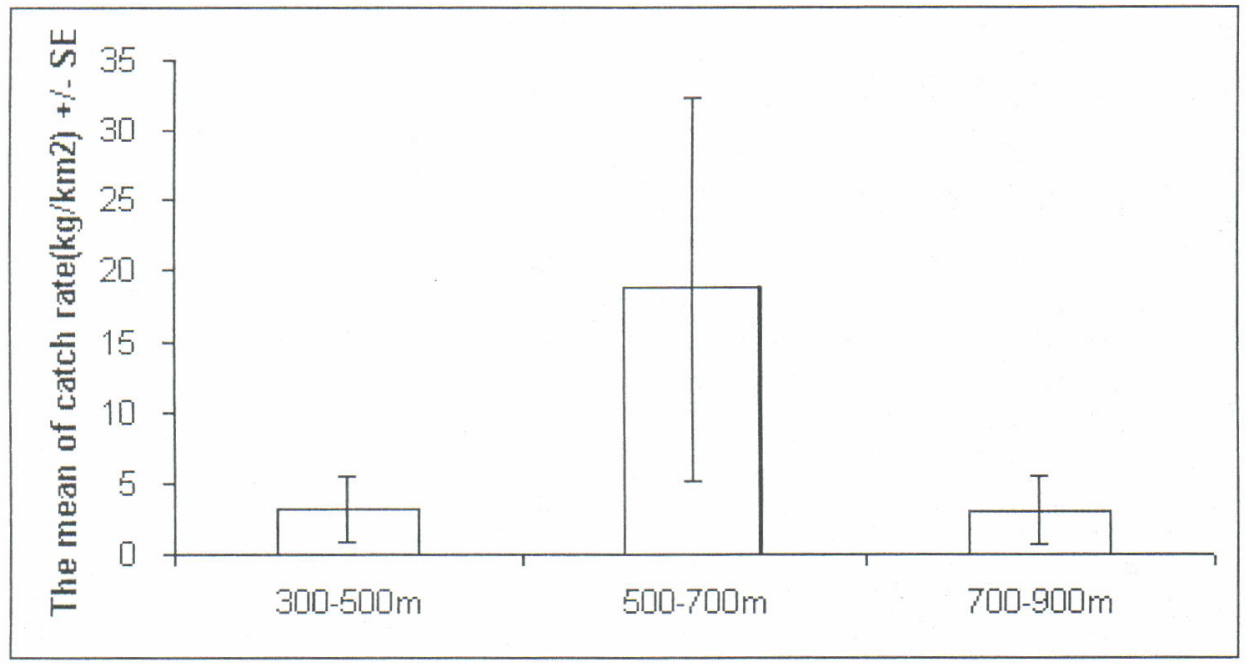

Figure 3 .

The average of catch rate on the basis of depth strata.

In term of vertical distribution the catches were higher in the depth from 500 to $700 \mathrm{~m}$. At the depth ranges of 200 to $300 \mathrm{~m}$ and 700 to $900 \mathrm{~m}$ the catch relatively small in quantity. For the depth 700 to 900 $\mathrm{m}$ Beryx splendens caught have bigger average in body size than those from 200 to $300 \mathrm{~m}$ (Figure 3).
The biggest catch at station no. 067 (519 m) contained 147 individuals. This suggested that Beryx splendens has a habitat preferences that might be due to physical factors i.e. temperature, sea bed type, or food availability. 
The evidence that Beryx splendens seems likely to inhabit the area that attributes specific habitat proved by the fish finder that showed the schooling commonly clumped close to the rough seabed, hills, or seamount tips.
The estimation of stock density of Beryx splendes in the southern of jawa was $68.6 \mathrm{~kg} \mathrm{~km}^{-2}$ tonnes while in the western of Aceh is $607.8 \mathrm{~kg} \mathrm{~km}^{-2}$ and 5995.81 tones (Table 1). Compare to the total catch $(11,813.4$ $\mathrm{kg}$ ) Beryx splendens was about $141.5 \mathrm{~kg}$. This revealed the species contributes a small quantity in the entire catches for $1.9 \%$.

Table 1.

Stock size of Beryx splendens on the surveyed area

\begin{tabular}{lcc}
\hline \multicolumn{1}{c}{ Parameters } & Southern of Jawa & Western of Aceh \\
\hline Total catch rate $\left(\mathrm{kg} \mathrm{km}^{-2}\right)$ & 12.34 & 127.635 \\
Average $\left(\mathrm{kg} \mathrm{km}^{-2}\right)$ & 2.06 & 18.23 \\
Swept area $\left(\mathrm{km}^{2}\right)$ & 0.06 & 0.06 \\
Stock density $\left(\mathrm{kg} \mathrm{km}^{-2}\right)$ & 68.56 & 607.79 \\
area $\left(\mathrm{km}^{2}\right)$ & 11019 & 9865.00 \\
Biomass (tones) & 755.41 & 5995.81 \\
Fishing potency (tones per year) & 377.71 & 2997.90 \\
\hline
\end{tabular}

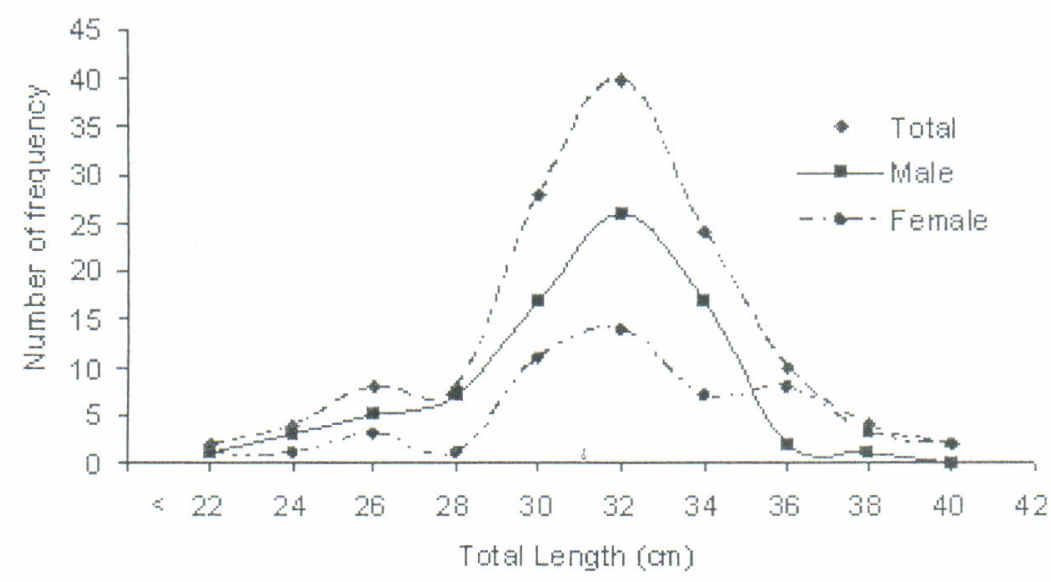

Figure 4. Length frequency distribution of the Alsfonsino (Beryx splendens).

\section{Length Distribution}

From a total of 130 sampled fish consisted of 51 females and 79 males. The species has one strong mode (Figure 4). The total trend of the population representing a relatively similar pattern to the slimeheads $(H$. crassispinus) reported by Badrudin et al. (2007). How ever the cohorts of female Alfonsino are likely consited of three age groups that represented by the length groups of approximately 26,32 , and $36 \mathrm{~cm}$. While male Alfonsino are likely consisted of two cohorts that represented by the length of approximately 26 and $32 \mathrm{~cm}$.

From a total of 583 fish sampled from different depth the fork length size of the Alfonsino, Beryx splendens was ranged from 12 to $34 \mathrm{~cm}$ (Figure 5). The distribution of this species with respect to the depth and size revealed that the large size of Beryx splendens were likely to found in the depth stratum of 400 to $500 \mathrm{~m}$ while the small size were likely inhabit and found in shallower water column i.e. 300 to 400 $\mathrm{m}$. Fish with length size of $<22 \mathrm{~cm}$ was likely to inhabit the water column less than $400 \mathrm{~m}$ while the bigger fish size $>25 \mathrm{~cm}$ was likely to found at deeper water column 400 to $600 \mathrm{~m}$ (Figure 5). If size related to the age this pattern might indicates that there was a shifting behaviour or physiology of the species when they reached a certain size and age.

\section{Sex Ratio and Maturity}

Data on sex ratio were recorded from 130 samples. There were 51 samples females (39.23\%) while 79 samples males $(60.77 \%)$ revealed the population was dominated by male (Figure 6 ). 


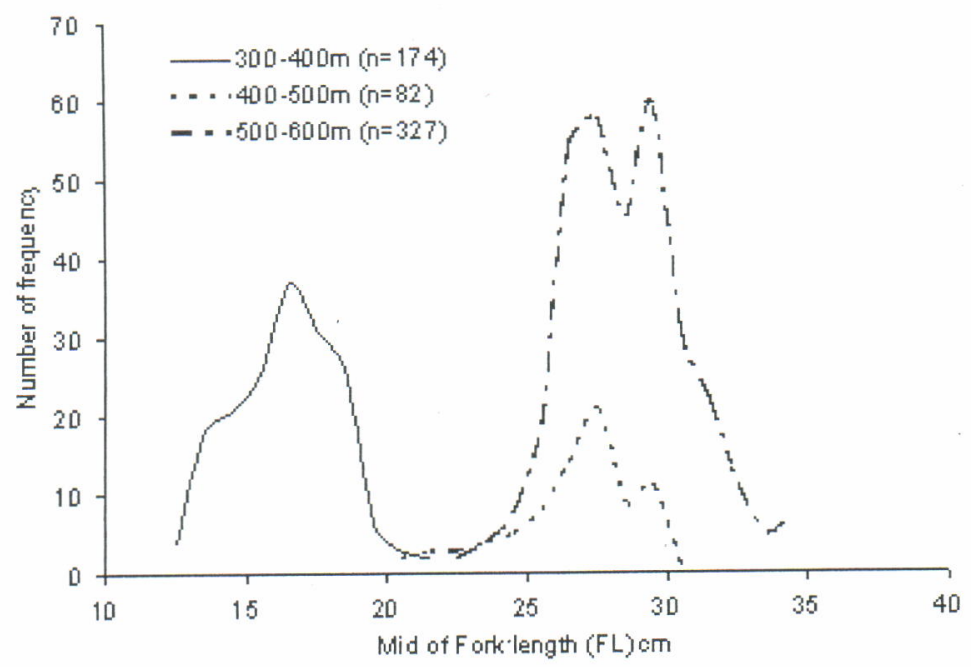

Figure 5. Length distribution by depth of the Alfonsino (Beryx splendens).
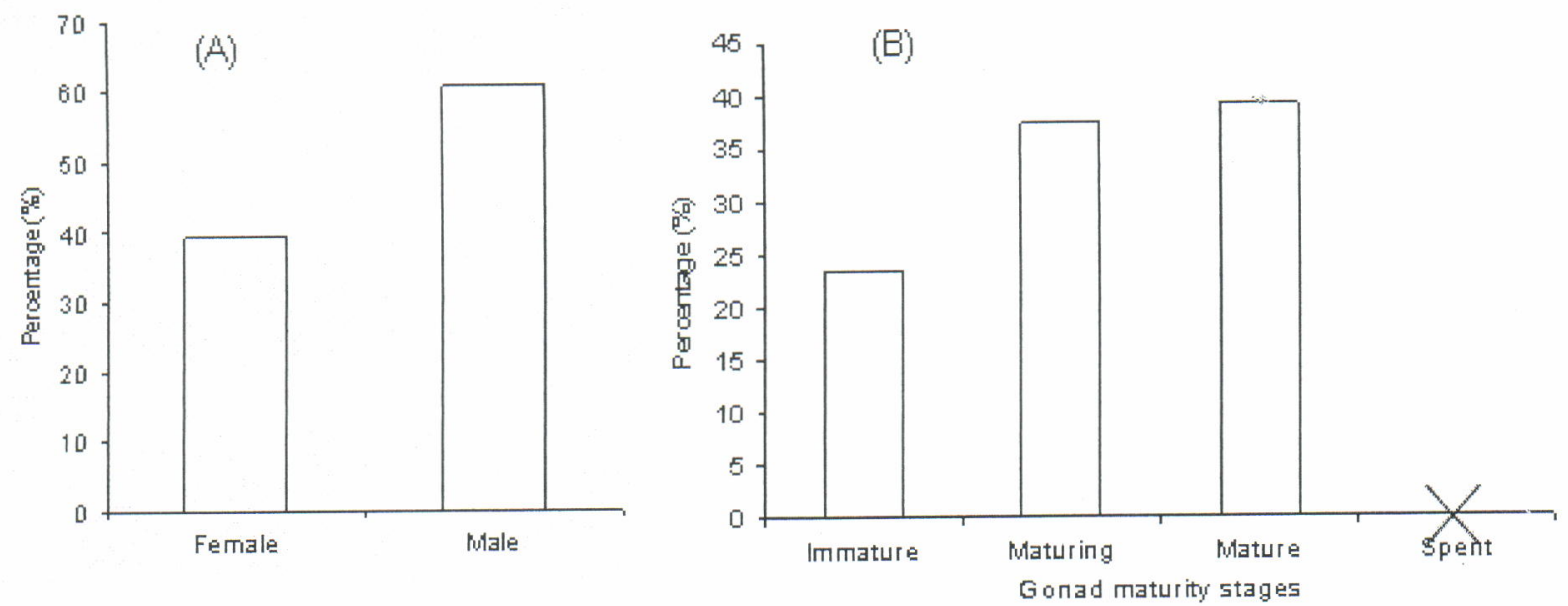

Figure 6. (A) sex ratio and (B) gonad maturity of the Alfonsino (Beryx splendens).

The maturity stages of females were recorded for 51 females i. e. $39.2 \%$ mature, $37.3 \%$ maturing, $23.5 \%$ immature, and no gonads were found in the stage of spent (Figure 7).

The average weight of maturing gonad was $2.4 \mathrm{gram}$ while the mature gonad was $4.4 \mathrm{~g}$. There were 20 samples of mature gonad out of 51 samples giving a moderate breeding proportion index i.e. $0.39(\mathrm{BP}=$ Total number of gonad, $51 /$ number of mature gonad, $20)$. Average of gonado somatic index for female was $2.8 \%(0.3$ to $7.4 \%)$.

\section{Length of First Maturity}

Identification of length of first maturity was based on female Alfonsino and defined as length group or class at which $50 \%$ of the fish in the group is already mature. From a number of 51 females of fish sampled, there were 12 immature, 19 maturing, and 20 mature (Table 2).

It was found that the length of first maturity of the Alfonsino was $L m=33 \mathrm{~cm}$, with $95 \%$ confidence limits of 31.2 to $34.9 \mathrm{~cm}$ total length. The estimation might be considered by the manager of the fishery, that the Alfonsino would be caught bigger than the size of $\mathrm{Lm}$, to ensure the sustainability of the fish stock.

\section{Diet}

A total of 40 stomachs were examined for food. There were more than $75 \%$ the stomach of the Alfonsino, Beryx splendens in western of Aceh found filled and up to $25 \%$ (18) empty (Figure 8 ).

The most common food items in the Alfonsino stomach were shrimps and small fish and small 
squids. Shrimps occurred in $60 \%$ of the stomachs, followed by small fishes (Myctophidae, Nemichthys) $29 \%$ and squids $11 \%$. Sergestidae, Sergestes spp. was common species of the shrimps while commonspecies of the small fishes was $C$. sloani and Diaphus sp. This suggested that Beryx splendens is a carnivore fish that mainly prey shrimps and Myctophids. Since the preys were mobile benthopelagic fish might suggested that the Alfonsino, Beryx splendens could be an active and relatively mobile species to search food.

Figure 7. Gonad weight in relation to gonad maturity stages (IM = Immature; $M T=M a t u r i n g ; M=$ mature).

Table 2. The estimation of length at first maturity of Alfonsino, Beryx splendens (Udupa, 1986 in Badrudin et al., 2007)

\begin{tabular}{|c|c|c|c|c|c|c|c|c|c|c|}
\hline $\begin{array}{l}\text { Length } \\
\text { group }\end{array}$ & $\begin{array}{c}\text { Mid } \\
\text { length }\end{array}$ & $\begin{array}{l}\text { Log. } \\
\text { Mid length } \\
\text { (Xi) }\end{array}$ & $\begin{array}{c}\text { No. } \\
\text { sample } \\
\text { (Ni) }\end{array}$ & Immature & Maturing & $\begin{array}{c}\text { Fully } \\
\text { mature }\end{array}$ & $\begin{array}{c}\text { Prop. } \\
\text { fully mature } \\
\text { (ri) }\end{array}$ & $\begin{array}{l}X i+1- \\
X i=X \\
(p i)\end{array}$ & $\begin{array}{l}q i= \\
1-p i\end{array}$ & $\begin{array}{c}\text { (pi.qi)/ } \\
\text { (ni-1) }\end{array}$ \\
\hline $23-25$ & 24 & 1.3802 & 2 & 2 & & & & & & \\
\hline $25-27$ & 26 & 1.4150 & 3 & 3 & & & & 0.0348 & & \\
\hline $27-29$ & 28 & 1.4472 & 1 & & 1 & & & 0.0322 & & \\
\hline 29-31 & 30 & 1.4771 & 11 & 3 & 5 & 3 & 0.2727 & 0.0300 & 0.7273 & 0.0198 \\
\hline $31-33$ & 32 & 1.5051 & 14 & 3 & 7 & 4 & 0.2857 & 0.0280 & 0.7143 & 0.0157 \\
\hline $33-35$ & 34 & 1.5315 & 7. & 1 & 3 & 3 & 0.4286 & 0.0263 & 0.5714 & 0.0408 \\
\hline $35-37$ & 36 & 1.5563 & 8 & & 3 & 5 & 0.6250 & 0.0248 & 0.3750 & 0.0335 \\
\hline $37-39$ & 38 & 1.5798 & 3 & & & 3 & 1.0000 & 0.0235 & & \\
\hline $39-41$ & 40 & 1.6021 & 1 & & & 1 & & & & \\
\hline \multirow[t]{2}{*}{$41-43$} & 42 & 1.6232 & 1 & & & 1 & & & & \\
\hline & & & 51 & 12 & 19 & 20 & 2.6120 & 0.0285 & & 0.1098 \\
\hline
\end{tabular}

Remarks:

Underlined $\rightarrow$ Last $\log$ size at wich $100 \%$ fully mature

$m=1.5798+(0,0285 / 2)-\left(0.0285^{*} 2.612\right) ; m=1.5196 ;$ Antilog $(1.5196)=33.03 \mathrm{~cm} \rightarrow \mathrm{Lm}=33 ; 95 \%$ Confidence limit; Upper limit Antilog $\left(1.5196+2.612\right.$ Sqrt $\left.\left(0.0285^{2 *} 0.1098\right)\right)=34.9 \mathrm{~cm}$; Lower Limit: Antilog $\left(1.5196+2.612 \mathrm{Sqrt}\left(0.0285^{2 *} 0.1098\right)\right)=31.2 \mathrm{~cm}$

\section{Commercial Fishing Using Deep Sea Bottom Trawl (the Recent Practice)}

Commercial fishing of the deep sea demersal fish resources has been conducted during January to May 2008 by F/B Koshin Maru 01. The fishing operation was focused at around western of Simeulu Island. The catch retained in the fish hold is Alfonsino and there were about $49 \%$ of the total catches was this species. The length size of Alfonsino caught was range from 10 to $40 \mathrm{~cm}$. The length distribution of the catch revealed that the Alfonsino has four age groups 
represented by the length of groups of approximately $13,17,24$, and $32 \mathrm{~cm}$ (Figure 9). The trend showed a more wide range of the species length size and gave more cohorts. The figure informed that a substantial decline occurred to the caught of the Alfonsino, Beryx splendens for the second and the third trips.
The recent practice of deep sea demersal fishes resources by F/B Koshin Maru showed that the gears caught substantial number of small fish of the Alfonsino with length of size smaller than $\operatorname{Lm}(33 \mathrm{~cm})$. This should become a warning to the fisheries manager that the recent fishing by deep sea bottom trawler will potentially endanger the resources.

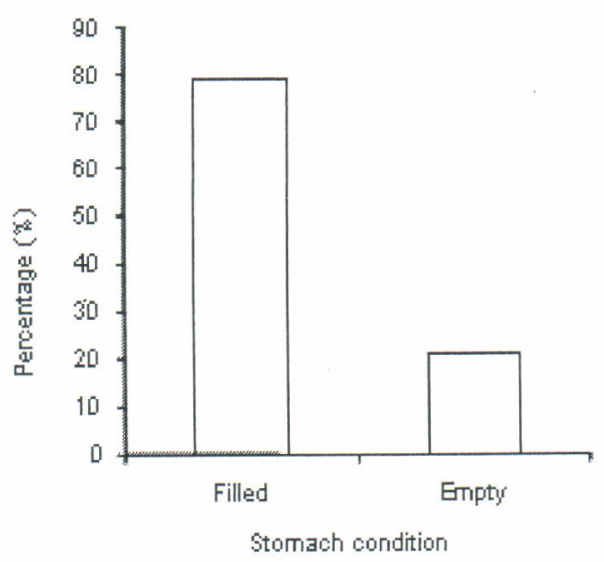

Figure 8. Stomach content of the Alfonsino (Beryx splendens)

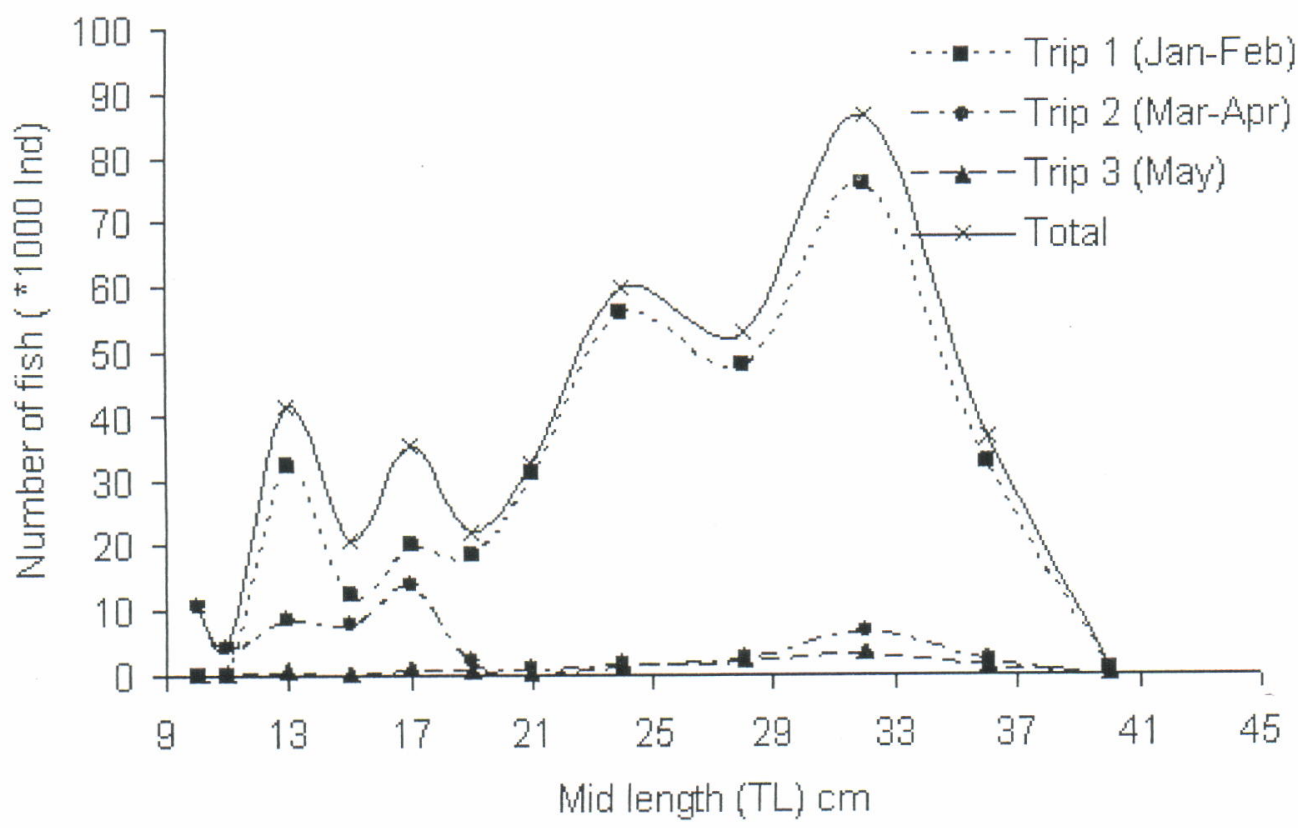

Figure 9. Length distribution of the Alfonsino caught using F/B Koshin Maru 01 during January to May 2008.

\section{CONCLUSION}

Stock density of the Alfonsino, Beryx splendens in average occurred in West Aceh waters for 607.79 $\mathrm{kg} \mathrm{km}^{-2}$ while in South Jawa $68.56 \mathrm{~kg} \mathrm{~km}^{-2}$. The species were more abundant in the depth range of 400 to $500 \mathrm{~m}$. The fish indicate a shifting behaviour to choose deeper part $(>300 \mathrm{~m}$ ) as grow bigger $(>25$ $\mathrm{cm}$ ). The length of first maturity of the Alfonsino was
$\mathrm{Lm}=33 \mathrm{~cm}$, with $95 \%$ confidence limits of 31.2 to $34.9 \mathrm{~cm}$ of total length. The most common food items in the Alfonsino stomach were shrimps $(60 \%)$ and small fish (29\%) and small squids (11\%). Beryx splendens is an active carnivore fish to search foods with main prey of shrimps (Sergestes spp.), mycthopids, and squids. The maturity stages of females were recorded for 51 females i.e. $39.2 \%$ mature, $37.3 \%$ maturing, $23.5 \%$ immature and no 
gonads were found in the stage of spent. Female Alfonsino are likely consisted of three age groups that represented by the length groups of approximately 26, 32, and $36 \mathrm{~cm}$. While male Alfonsino are likely consisted of two cohorts that represented by the length of approximately 26 and $32 \mathrm{~cm}$. From the commercial catch it is revealed that the length size range of the Alfonsino is 10 to $40 \mathrm{~cm}$ and likely has four age groups represented by the length of groups of approximately $13,17,24$, and $32 \mathrm{~cm}$. The recent practice of deep sea demersal fishes resources utilization by F/B. Koshin Maru 01 showed that the deep sea trawler also caught in substantial number small size of the Alfonsino that much lower from the $\mathrm{Lm}$ size of the Alfonsino ( $\mathrm{Lm} 33 \mathrm{~cm}$ ). This should become a warning to the fisheries manager that the recent operation of deep sea bottom trawler could threaten the resources and should manage with a very careful precautionary approach.

\section{ACKNOWLEDGEMENTS}

This paper is part of the Indonesia-Japan joint exploration project of the deep sea fisheries resources funded by Overseas Fishery Cooperation FoundationJapan and Agency for Marine and Fisheries Research year 2005; The commercial fishing trial on the deep sea fisheries resources in the Indian Ocean funded by The Japan Deep Sea Trawl Association and Fishing Technology Development Center year 2008.

\section{REFERENCES}

Anonymous. 2006. The Japan-Indonesia deep sea fishery resources joint exploration project (report of 2005 field survey). Overseas Fishery
Cooperation Foundation-Research Institute for Marine Fisheries.

Badrudin, A. Suman, \& Awwaludin. 2007. Size distribution and maturity of the slimeheads (Hoplostethus crassispinus) in the deep sea around Simeulu Island. Western Sumatera. Eastern Indian Ocean

Clark, M. \& O, Richard. 2003. Deepwater fisheries and aspects of their impact on seamount habitat in New Zealand. Journal Northw. Atl. Science. Vol.31. 441-458.

Maul, G. E. 1990. Beryx splendens. http:// www. fishbase.org/. Download 19 Agustus 2008 pukul 14.00

Nakabo, T. 2000. Fishes of Japan with pectoral keys to the species. Second Edition. Tokai University Press. Tokyo. Book I. 1-866 pp.

Nakabo, T. 2000. Fishes of Japan with pectoral keys to the species. Second Edition. Tokai University Press. Tokyo. Book II. 867-1749 pp.

Sparre, P. \& S. C. Venema. 1992. Introduction to tropical fish stock assessment. Part 1. Manual. F. A. O. Fishery Tech. Pap. No.306/1. Rev. 1.

Suseno, S. H., A. Suman, Wudianto, \& Arin D. 2007. Nutrient and steroid contents of some deep sea fish species from western Sumatera, Eastern Indian Ocean. Indonesian Fisheries Research Journal. Vol.13. No.1. P 1-8. 